\author{
Paulina BĘDŹmirowska ${ }^{1}$
}

\title{
O roli orzecznictwa TSUE w procesie harmonizacji prawa Unii Europejskiej z prawem krajowym
}

Polska, jako kraj członkowski, wraz z wejściem w życie traktatu akcesyjnego, została związana całym prawem pierwotnym oraz dorobkiem wspólnotowym (acquis communautaire), który obejmuje zarówno prawo pochodne, jak i wykładnię prawa unijnego zawartą w orzecznictwie Trybunału Sprawiedliwości Unii Europejskiej (dalej TSUE). Hybrydowa struktura UE widoczna jest zarówno w podstawach funkcjonalnych określonych w prawie traktatowym, jak też w procesie decyzyjnym. Unia zbudowana jest na podstawie Wspólnot (Wspólnoty Europejskiej oraz Europejskiej Wspólnoty Energii Atomowej - Euratom) uzupełnionych politykami i formami współpracy ustanowionymi w Traktacie o Unii Europejskiej (TUE). Pomiędzy obszarem wspólnotowym a politykami i formami współpracy istnieje zasadnicza różnica. Obszar wspólnotowy ma wyraźny charakter ponadnarodowy, regulowany jest za pomocą specyficznych środków prawnych, przyjmowanych generalnie z zastosowaniem procedury większości kwalifikowanej z inicjatywy Komisji po konsultacjach z Parlamentem Europejskim. Nad utrzymaniem porządku prawnego UE czuwa Trybunał Sprawiedliwości Unii Europejskiej (dalej TSUE lub Trybunał).

Z uwagi na ścisłe związanie polskiej legislacji z prawem Unii Europejskiej przez konieczność stosowania w procesie jego wdrażania szeregu unijnych aktów prawnych, tj. rozporządzeń, dyrektyw, a także aktów prawa miękkiego, tj. wytycznych czy zaleceń, które nie są aktami powszechnie obowiązującego prawa, pojawia się problem zakresu stosowania prawa UE na gruncie polskiego systemu prawnego, tę lukę w sensie prawnym, w znacznym zakresie, wypełniło orzecznictwo TSUE.

Na prawo krajowe oddziałują także odnoszące się do prawa europejskiego zasady: autonomii prawa UE, zasada pierwszeństwa prawa UE wobec prawa państw członkowskich oraz zasada bezpośredniego skutku prawa UE. Normy prawa unijnego stały się po akcesji Polski do UE częścią systemu prawa krajowego, są wobec tego stosowane powszechnie i mają wiążącą moc.

Fundacja Programów Pomocy Dla Rolnictwa FAPA. 
Sytuacja taka prowadzi w sposób nieunikniony do trudności w określeniu pochodzenia zmian ustrojowych, tj. czy mają one swoje źródło w prawie krajowym, czy w prawie unijnym. Także zadania krajowych organów uległy rozszerzeniu o przepisy prawa unijnego, prawo to wykonują bowiem organy UE, ale w przeważającej części obowiązki z niego wynikające wykonują organy krajowe stając się niejako organami UE. Zmiany w administracji wynikają z umów międzynarodowych, z prawodawstwa krajowego oraz z prawa unijnego bezpośrednio i pośrednio obowiązującego - rozporządzeń, dyrektyw, decyzji, soft law, ${ }^{2}$ a także z orzecznictwa Trybunału Sprawiedliwości.

Od czasu akcesji Polski do UE wraz z wdrażaniem funduszy współfinansowanych z Unii Europejskiej zaczęto znacznie bardziej odczuwać prawotwórczą rolę TSUE. Poza orzecznictwem wydawanym przez Trybunał, także w dużym stopniu wydawane są odpowiedzi na pytania prejudycjalne polskich sądów, a także sądów pozostałych państw członkowskich. Trybunał orzeka we wnoszonych do niego sprawach, do których najbardziej powszechne są sprawy dotyczące wykładni prawa (wydawania orzeczeń w trybie prejudycjalnym), egzekwowanie prawa (postępowania w sprawie uchybienia), unieważnianie aktów prawnych (skargi o unieważnienie), zapewnianie podejmowania działań przez UE (skargi w sprawie bezczynności), skargi na instytucje UE (roszczenia o odszkodowanie). W sytuacji oddziaływania prawa UE na prawo krajowe mogą powstawać sytuacje kolizyjne wymagające posłużenia się analizą porównawczą konkretnych norm. Z taką sytuacją mamy do czynienia często, gdy stosownie do wymagań formułowanych w orzecznictwie TSUE organy administracyjne stosując $w$ indywidualnych sytuacjach prawo krajowe obowiązane są uwzględniać normy prawa unijnego i zapewniać mu odpowiednią efektywność.

TSUE zdecydowanie konfirmuje pierwszeństwo prawa unijnego przed wszystkimi normami prawa krajowego, także zawartymi w Konstytucji. ${ }^{3}$ Należy jednak wspomnieć, iż sądy konstytucyjne niektórych państw członkowskich, tj. np. Niemiec czy Włoch, wnoszą zastrzeżenia do tezy o pierwszeństwie prawa UE wobec norm konstytucyjnych swoich porządków prawnych.

„Miękkie prawo" europejskie nie podlega obowiązkowi formalnej transpozycji, możemy jednak aktualnie zaobserwować, że coraz szerszym strumieniem przedostaje się ono do prawa stanowionego. W piśmiennictwie zauważa się nawet, że soft law może stanowić alternatywę dla harmonizacji przez dyrektywy. Podkreśla się, że różnica między dyrektywami a soft law staje się coraz bardziej płynna. Procesy europeizacji prawa prowadzące do harmonizacji porządków prawnych państw członkowskich, które tradycyjnie opierały się na dyrektywie jako podstawowym instrumencie prawnym, są coraz częściej realizowane za pomocą soft law.

Por. orzeczenie Costa z dnia 15 lipca 1964, orzeczenie 11/70 Internationale Handelsgesellschaft v. Einfuhr - Und Vorratstelle fur Getreide Und Futtermittel, Zb. Orz. 1970, s. 1125, orzeczenie 106/77 Amminisrazione delle Finanze dello Stato v.Simmenthal,Zb. Rz. 1978, s. 629, orzeczenie C-224/97 Ciola v.Land Vorarlberg, Zb.Orz. 1999, s.I-2517, orzeczenie C-10-22/97 Ministero delle Finanze v.IN.CO.GE.'90 Srl, Zb.Orz. 1998, s.I-6307, -87/02, C-391/02, C-403/02 z dnia 3 maja 2005r., sprawa C-105/03 z dnia 16 czerwca 2005 r. 
Wskazane wyżej zagadnienie znalazło rozwiązanie w bardzo obszernym orzecznictwie TSUE, w którym stwierdził, że przez włączenie do wspólnotowego porządku prawnego wynikających z Traktatu praw i obowiązków, dotychczas unormowanych w prawie krajowym, państwa członkowskie trwale ograniczyły swoje suwerenne prawa i w konsekwencji nie mogą ustanawiać regulacji sprzecznych z istotą Unii. Ponadto, stosowanie prawa wynikającego z Traktatu nie może być wyłączone przez przepisy krajowe, gdyż podważałoby to podstawy prawne funkcjonowania UE. W aspekcie czasowym, w świetle orzecznictwa TSUE, z pierwszeństwa korzystają normy prawa unijnego niezależnie od tego, czy są wcześniejsze, czy późniejsze, niż niezgodne z nimi normy prawa krajowego. ${ }^{4}$ Co więcej, zgodnie z orzecznictwem TSUE, organy państw członkowskich są obowiązane do podejmowania działań (lub ich zaniechania), zgodnych z treścią norm dyrektyw, nawet w sytuacji, gdy dyrektywy nie zostały prawidłowo implementowane do prawa krajowego. 5

TSUE uznał, ${ }^{6}$ że sąd krajowy powinien interpretować prawo krajowe przez pryzmat przepisów i celów dyrektyw wspólnotowych, także w wypadku braku krajowych przepisów implementujących. Podobnie jest np. w odniesieniu do rozporządzeń, gdzie coraz częściej mamy do czynienia z sytuacją, w której akty kwalifikujące się jako rozporządzenia wymagają dla ich rzeczywistej skuteczności wprowadzenia dodatkowych przepisów krajowych. ${ }^{7}$

W tym kontekście warto wspomnieć, że Trybunał Sprawiedliwości Unii Europejskiej bardzo dużą wagę przywiązuje do znaczenia normatywnego przepisów Traktatu w zakresie Wspólnej Polityki Rolnej. Trybunał, mimo że uznawał szeroką dyskrecjonalność decyzyjną instytucji europejskich w zakresie przyjmowania środków dla realizacji jednego bądź drugiego celu WPR, ${ }^{8}$ nie wahał się uchylać aktów o charakterze powszechnie obowiązującym, ocenionych jako sprzeczne z przedmiotem lub celami polityki rolnej wynikającymi z Traktatu rzymskiego bądź traktatów akcesyjnych. ${ }^{9}$

4 Por. orzeczenie 106/77 Amminisrazione delle Finanze dello Stato v.Simmenthal, Zb. Rz. 1978, s. 629.

5 Por. orzeczenie C-431/92 Commission v.Germany, Zb.Orz. 1995, s. I-2189

6 Por. orzeczenie ETS z 14 lipca 1994 r. w sprawie Faccini Dori, sygn. C-91/92.

7 F. Albisinni, Europejskie prawo rolne po Traktacie z Lizbony pomiędzy interwencją a regulacją. Europejskie kodeksy rolnictwa, „Przegląd Prawa Rolnego” 2011, Nr 1, s. 115.

8 Na ten temat zob. L. Costato, Agricoltura, [w:] M. Chiti, G.Greco (red.), Trattato di diritto amministrativo europeo, t. I, Milano 1957, s.1, za: F. Albisinni, Europejskie prawo rolne po Traktacie z Lizbony pomiędzy interwencją a regulacją. Europejskie kodeksy rolnictwa, „Przegląd Prawa Rolnego” 2011, Nr 1, s. 118.

9 Za: F. Albissini, Europejskie prawo rolne po Traktacie z Lizbony pomiędzy interwencją a regulacją. Europejskie kodeksy rolnictwa, „Przegląd Prawa Rolnego” 2011, Nr 1, s. 118, który przytacza tu orzeczenie z 25 lutego 1997 r. w sprawach połączonych C-164/97 i C-165/97, w którym ETS uznał za niezgodne z prawem niektóre rozporządzenia w przedmiocie ochrony lasów przejęte przez Radę na podstawie art. 43 Traktatu, stwierdzając, że podstawy prawnej tych rozporządzeń, ze względu na to, że dotyczyły one produktów leśnych, które nie są wymienione w Załączniku II Traktatu, należało szukać raczej w przepisach dotyczących ochrony środowiska, co z kolei pociągałoby za sobą zastosowanie innej procedury prawodawczej w tych przepisach. Przywołać można także orzeczenie z dnia 7 września 2006 r. w sprawie C-310/04, w której, uznając skargę przedstawioną przez Hiszpanię, TS uznał za niezgodne z prawem rozporządzenie Rady (WE) nr 864/2004 rozciągające reżim płat- 
Orzecznictwo TSUE w zakresie tożsamości prawno-instytucjonalnej Wspólnot Europejskich i Unii Europejskiej zostało przeniesione do projektu Konstytucji UE, która sankcjonuje orzecznictwo TSUE w kwestii prymatu prawa wspólnotowego nad prawem krajowym państw członkowskich. Art. I-10 ust. 1 brzmi następująco: „Konstytucja i prawo przyjęte przez instytucje Unii w wykonywaniu kompetencji powierzonych im na mocy Konstytucji mają prymat nad prawem państw członkowskich”. Z kolei w postanowieniach końcowych zapisano, że „orzeczenia Trybunału Sprawiedliwości Wspólnot Europejskich zostaną utrzymane jako źródło interpretacji prawa Unii" (art. IV-2).

Trybunał Sprawiedliwości czuwa nad przestrzeganiem zasady prymatu prawa UE. Jego dotychczasowe ogólne kompetencje, określone w art. 220 TWE, ${ }^{10}$ wyglądają następująco: „Trybunał Sprawiedliwości zapewnia poszanowanie prawa przy interpretacji i stosowaniu niniejszego Traktatu Orzeczenia Trybunału są ostateczne i nie ma od nich odwołania.

Granice jurysdykcji Trybunału Sprawiedliwości Unii Europejskiej (ratione materiae) określone zostały postanowieniami Traktatu ustanawiającego Wspólnotę Europejską. Art. 220 TWE stanowi, iż TSUE zapewnia przestrzeganie prawa przy wykładni i stosowaniu Traktatu. Na mocy art. 263 TFUE, TSUE bada zgodność z prawem aktów przyjętych wspólnie przez Radę i Parlament (zwykle rozporządzenia i dyrektywy) oraz Radę i Komisję (zwykle tzw. ustawodawstwo delegowane i akty o charakterze administracyjnym). Ust. 2 art. 263 TFUE stanowi, że TSUE orzeka unieważnienie danego aktu w oparciu o stwierdzenie braku kompetencji danego organu, naruszenia istotnych przepisów dotyczących formy aktu, naruszenia Traktatu lub jakiejkolwiek stosowanej normy prawnej lub z powodu nadużycia prawa do swobodnej oceny. W przypadku wystąpienia właściwych przesłanek TSUE orzeka unieważnienie nie tylko kwestionowanego aktu (jak klasyczne sądy międzynarodowe), ale także innych aktów wydanych na jego podstawie. ${ }^{11}$ Trybunał ogłasza akt jako nieważny i niebyły (por. art. 264 TFUE). Jeśli chodzi o skutki czasowe, orzeczenia wydawane na podstawie art. 263 TFUE mają charakter ex tunc i obowiązują erga omnes, co oznacza, że dany akt traktowany jest tak, jakby nigdy nie został podjęty.

Drugą procedurą, w ramach której możliwe jest badanie zgodności postanowień aktów prawnych z TFUE, jest procedura z art. 267 TFUE. Przepis ten stanowi, że TSUE rozstrzyga $w$ trybie orzeczenia wstępnego (prejudycjalnego):

ności jednolitej na bawełnę. Rozporządzenie to zostało zakwestionowane z powodu naruszenia zasady proporcjonalności, ponieważ Rada nie wykazała, że wzięła pod uwagę wszystkie istotne elementy, by zagwarantować spójność przyjętych działań z celami wyznaczonymi w Traktacie akcesyjnym Gracji i Hiszpanii w zakresie wsparcia da upraw bawełny.

10 Bez odpowiednika w TFUE.

11 M. Zaleśkiewicz, Co mówi prawo? Uwagi nad prawotwórczą wykładnią funkcjonalną w orzecznictwie Sądu Najwyższego Stanów Zjednoczonych i Europejskiego Trybunału Sprawiedliwości, op. cit., s. 63. 
a) o wykładni Traktatów,

b) o ważności i wykładni aktów przyjętych przez instytucje, organy lub jednostki organizacyjne Unii.

Ratio legis takiego rozwiązania podyktowane jest potrzebą jednolitego stosowania Traktatu we wszystkich państwach członkowskich. Interpretacja prawa unijnego i orzekanie o ważności aktów UE należą do wyłącznych kompetencji TSUE, podczas gdy rozstrzygnięcie konkretnego sporu spoczywa na sądach krajowych. Sąd krajowy występując z pytaniem prawnym, musi uzasadnić swoją decyzję, podając podstawę swego uznania, że udzielona przez TSUE odpowiedź w postaci orzeczenia prejudycjalnego jest potrzebna do rozstrzygnięcia sprawy zawisłej przed sądem krajowym. ${ }^{12}$

Według TSUE żadne przepisy prawa krajowego nie mogą dominować nad prawem wywodzącym się z Traktatu, będącego niezależnym źródłem prawa. Niezaprzeczalnie $\mathrm{z}$ takim rodzajem konfliktu obu porządków prawnych mamy do czynienia podczas wdrażania funduszy pochodzących z UE. Szereg aktów prawnych, których stosowania wymaga realizacja programów unijnych, powoduje niejednokrotnie problem nadrzędności stosowania poszczególnych norm. TFUE nie normuje wprost sposobów rozstrzygania konfliktów między normami prawa UE a normami prawa państw członkowskich. Powstają one w przypadku niezgodności norm należących do obu omawianych porządków prawnych, tj. w przypadkach, gdy nie można spełnić równocześnie norm należących do obu systemów prawnych, mających choćby częściowo wspólny zakres stosowania. To właśnie orzeczenia TSUE określiły zakres obowiązywania zasady pierwszeństwa. Zasada ta ma wobec norm prawa krajowego zasięg nieograniczony. Implikuje to z jednej strony pierwszeństwo korzystania ze wszystkich norm prawa UE, zawartych w prawie Unii, zarówno w prawie pierwotnym, jak i w wiążących aktach prawa pochodnego. Z drugiej strony, konsekwencje zasady pierwszeństwa obejmują wszystkie normy prawa krajowego. Państwo członkowskie nie może powołać się na żadne normy swojego porządku prawnego, które byłyby wyłączone spod działania zasady pierwszeństwa prawa UE, czyli faktycznie miały pierwszeństwo wobec norm tego prawa. Pierwszeństwo prawa Unii obejmuje również normy konstytucyjne państw członkowskich. ${ }^{13}$

Wskazane wyżej zagadnienie znalazło rozwiązanie w bardzo obszernym orzecznictwie TSUE, zaczynając od orzeczenia Costa z dnia 15 lipca 1964 r. (pytanie prejudycjalne), w którym TSUE stwierdził, że przez włączenie do wspólno-

12 Za niedopuszczalne uznał ETS rozpatrywanie pytań dotyczących kwestii ogólnych oraz pytań hipotetycznych, por. orzeczenie C-244/80 Foglia v. Novello.

13 Por. orzeczenie 11/70 Internationale Handelsgesellschaft v. Einfuhr - Und Vorratstelle fur Getreide Und Futtermittel, Zb. Orz. 1970, s. 1125. 
towego porządku prawnego wynikających z Traktatu praw i obowiązków, dotychczas unormowanych w prawie krajowym, państwa członkowskie trwale ograniczyły swoje suwerenne prawa i w konsekwencji nie mogą ustanawiać regulacji sprzecznych z istotą Unii. Ponadto, stosowanie prawa wynikającego z Traktatu nie może być wyłączone przez przepisy krajowe, gdyż naruszałoby to wspólnotowy charakter tego prawa i podważałoby podstawy prawne funkcjonowania Wspólnoty. W aspekcie czasowym, w świetle orzecznictwa TSUE, z pierwszeństwa korzystają normy prawa wspólnotowego niezależnie od tego, czy są wcześniejsze, czy późniejsze niż niezgodne $\mathrm{z}$ nimi normy prawa krajowego. ${ }^{14}$

W orzecznictwie TSUE zasada pierwszeństwa wykorzystywana była do rozstrzygania konfliktów między normami prawnymi sensu stricto, tj. mającymi charakter generalny i abstrakcyjny. Warto przy tej okazji zaznaczyć, że w wydanym przez siebie orzeczeniu TSUE zakwestionował także, z powołaniem się na zasadę pierwszeństwa prawa UE, pewne postanowienia zawarte w indywidualnej decyzji administracyjnej, wydanej w Austrii. Takie rozstrzygnięcie jest niewątpliwie kontrowersyjne, narusza bowiem zasadę trwałości prawomocnych decyzji administracyjnych. ${ }^{15}$

Na temat następstw zasady pierwszeństwa prawa UE wypowiedział się szerzej TSUE w orzeczeniu Simmenthal. ${ }^{16} \mathrm{~W}$ przedmiotowej sprawie pojawił się problem dotyczący ścieżki postępowania przez sąd państwa członkowskiego w sytuacji, gdy norma prawa krajowego nakłada na określonych przedsiębiorców - importerów towarów z innych państw członkowskich pewne obowiązki, które są niezgodne z normami prawa wspólnotowego. W przekonaniu TSUE, sąd powinien $\mathrm{w}$ takim przypadku odmówić zastosowania normy prawa krajowego. $\mathrm{Z}$ powołanego orzeczenia wynikają dwa istotne wnioski.

Po pierwsze, TSUE opowiedział się za ideą pierwszeństwa stosowania prawa UE, a nie pierwszeństwa obowiązywania. Stwierdzenie niezgodności z prawem UE normy prawa krajowego nie powoduje zatem mechanicznego uchylenia tej normy. Takie podejście jest łatwiejsze do zaakceptowania przez państwa członkowskie, ponieważ nie narusza ustalonych w prawie krajowym sposobów eliminowania norm z porządku prawnego. Kompetencje do uchylania norm prawnych przysługują, jak wiadomo, właściwym organom prawotwórczym, albo sądom konstytucyjnym, ale nie pozostałym sądom. Teza o pierwszeństwie stosowania prawa UE, w odróżnieniu 
od pierwszeństwa obowiązywania, została podtrzymana przez TSUE także w późniejszym orzecznictwie. ${ }^{17}$

Po drugie, w orzeczeniu Simmenthal, TSUE wyraził pogląd, że obowiązek odmowy zastosowania normy prawa krajowego niezgodnej z prawem UE spoczywa na każdym sądzie rozpoznającym sprawę. Konieczność czekania na orzeczenie innego, właściwego sądu byłaby bowiem osłabieniem efektywności prawa UE. W razie wątpliwości, czy rzeczywiście występuje niezgodność prawa krajowego z prawem UE, sąd państwa członkowskiego powinien, na podstawie art. 267 TFUE, wystąpić z zapytaniem wstępnym do TSUE. ${ }^{18}$

Podkreślony w orzeczeniu Simmenthal obowiązek wszystkich sądów państw członkowskich, właściwych w poszczególnych sprawach, do odmowy zastosowania prawa krajowego niezgodnego z prawem UE zasługuje na uwagę. Wymaga ono podkreślenia tym bardziej, że na podstawie prawa poszczególnych państw członkowskich, analogiczne kompetencje nie zawsze przysługują sądom w razie konfliktów między normami prawa krajowego, w szczególności w przypadkach niezgodności z konstytucją.

Warto przy tym rozważyć znaczenie stwierdzenia, że norma prawa krajowego niezgodna z prawem UE miałaby obowiązywać z tym, że nie znajdowałaby zastosowania. Oczywiście, nie znaczy to, że owa norma nie mogłaby znaleźć zastosowania w ogóle. Mogłaby ona być bowiem stosowana, jednakże poza zakresem obowiązywania prawa Unii.

W literaturze przedmiotu, także polskiej, ${ }^{19}$ znaleźć można przegląd rozwiązań konstytucyjnych poszczególnych państw członkowskich oraz orzecznictwa sądowego, dotyczącego zasady pierwszeństwa prawa UE. Wyjątki stanowią państwa, w których zasada ta została zaakceptowana bez trudności (np. Holandia). W pozostałych sądy stopniowo, często w ciągu wielu lat, akceptowały pozycję prawa UE. Oczywiście najtrudniejsze było zaakceptowanie pierwszeństwa prawa UE nad konstytucjami poszczególnych państw. Szczególne problemy wystąpiły zwłaszcza w Niemczech, Włoszech oraz Danii. Sądy konstytucyjne w niektórych państwach

17 Por. np. orzeczenie C-10-22/97 Ministero delle Finanze v.IN.CO.GE.'90 Srl, Zb.Orz. 1998, s. I-6307.

18 Za: Prawo Unii Europejskiej. Zagadnienia systemowe, Jan Barcz (red.), Warszawa 2002.

19 Por. np. J. Barcz, Stosowanie prawa Wspólnot Europejskich w państwach członkowskich, Warszawa 1991; M.A. Dauses, Prawo Wspólnot Europejskich a prawo niemieckie w świetle niemieckiego porządku konstytucyjnego, „Przegląd Prawa Egzekucyjnego” 1998, nr 1, s.23 i nast.; M. Górska, Relacje między prawem wspólnotowym, a prawem krajowym w prawie i praktyce sądowej państw członkowskich Unii Europejskiej, [w:] C. Banasiński, J. Oniszczuk (red.), Konstytucja - Trybunał Konstytucyjny, Warszawa 1998, s. 94 i n.; E. Podgórska, Problem pierwszeństwa prawa Wspólnot Europejskich wobec prawa krajowego w orzecznictwie włoskiego Trybunału Konstytucyjnego, „Państwo i Prawo” 1994, nr 11, s. 59 i n.; P. Saganek, Orzecznictwo sądów krajowych państw członkowskich dotyczące Wspólnot Europejskich, [w:] C. Mik (red.), Wymiar sprawiedliwości w Unii Europejskiej, Toruń 2001, s.147 i n. 
członkowskich w rzeczywistości do tej pory nie uznają bez zastrzeżeń tego, iż to TSUE miałby mieć decydujące zdanie w razie konfliktu między prawem Unii a konstytucjami państw członkowskich. Sytuacje, w których normy konstytucyjne państw członkowskich są niezgodne z prawem UE są rzadkie, choć nie można ich oczywiście wykluczyć. Kontrowersje na tej płaszczyźnie mają jednak charakter bardziej symboliczny niż realny.

Przy okazji omawiania pierwszeństwa stosowania i bezpośredniej skuteczności prawa UE w stosunku do prawa krajowego danego państwa członkowskiego na uwagę zasługują wyroki TSUE i SPI wydane w latach 1963-2005, które ukształtowały treść i ramy pierwszeństwa prawa UE w krajowych porządkach prawnych. ${ }^{20}$ Są to najważniejsze orzeczenia dotyczące relacji między przepisami prawa UE a normami konstytucyjnymi państw członkowskich.

Funkcjonowanie zasady pierwszeństwa jest ściśle związane z bezpośrednią skutecznością prawa UE i z problematyką stosowania tego prawa przez sądy i organy administracji. $Z$ tego względu poniżej omówiono kilka wyroków dotyczących tych zagadnień, które składają się na obraz obecnej pozycji prawa Unii Europejskiej.

W szczególności, orzeczenia te wyznaczają granice bezpośredniej skuteczności prawa wspólnotowego (wyrok w sprawie Berlusconi ${ }^{21}$ ) oraz zakres obowiązku wykładni prawa krajowego w zgodzie z prawem UE na gruncie III filaru (orzeczenie w sprawie Pupino ${ }^{22}$ ). Wyroki Sądu Pierwszej Instancji (zwanego dalej SPI) w sprawach Yusuf $i$ Kadi $^{23}$ wskazują m.in. na pierwszeństwo wynikających z Karty Narodów Zjednoczonych obowiązków państw członkowskich ONZ przed postanowieniami Konwencji o ochronie praw człowieka i podstawowych wolności oraz Traktatu Ustanawiającego Wspólnotę Europejską. Z kolei akty prawne UE stanowiące implementację prawa tworzonego przez organy Narodów Zjednoczonych podlegają kontroli SPI z punktu widzenia zgodności z międzynarodowymi normami iuris cogentis.

W sprawie 26/621 Van Gend en Loos (pytanie prejudycjalne) z dnia 5 marca 1963 r. główne tezy wygłoszone tu przez TSUE stanowiły, iż UE stanowi nowy porządek prawnomiędzynarodowy, na rzecz którego państwa członkowskie ograniczyły w określonym zakresie swoje suwerenne prawa. Podmiotami tego porządku prawnego są zarówno państwa członkowskie, jak i ich obywatele. Ponadto, art. 30

Za: Biuro Trybunału Konstytucyjnego Zespół Orzecznictwa i Studiów „Zasada pierwszeństwa prawa wspólnotowego w krajowych porządkach prawnych według orzecznictwa ETS i Sądu Pierwszej Instancji”. Omówienia wybranych orzeczeń (1963-2005) P. Miklaszewicza (red.). 
TFUE zawiera wyraźny i bezwarunkowy zakaz, którego przestrzeganie nie jest uzależnione od przyjęcia przez państwa członkowskie jakiejkolwiek regulacji prawnej stanowiącej jego implementację. W konsekwencji przepis ten jest bezpośrednio skuteczny i kreuje prawa podmiotowe, które powinny być chronione przez sądy narodowe.

Dalsze tezy wysuną TSUE w wyroku w sprawie 11/704 Internationale Handelsgesellschaft z dnia 17 grudnia 1970 r. (pytanie prejudycjalne), gdzie stwierdził, że prawo wspólnotowe wynikające z Traktatu, jako niezależnego źródła prawa, ze względu na swą istotę nie może być uchylone przez przepisy prawa krajowego i to niezależnie od ich rangi. Ważność działań instytucji UE lub skutki takich działań w państwie członkowskim nie mogą być podważane ze względu na niezgodność z prawami podstawowymi wynikającymi z konstytucji państwa członkowskiego.

Ponadto, TSUE stoi na stanowisku, że nie do pogodzenia z wymogami wynikającymi z samej natury prawa unijnego byłyby przepisy krajowe, jak również praktyka legislacyjna, administracyjna lub sądowa, które prowadziłyby do zmniejszenia skuteczności prawa wspólnotowego, pozbawiając sąd krajowy orzekający w sprawie i stosujący prawo wspólnotowe możliwości uczynienia wszystkiego, co konieczne, aby uchylić stosowanie prawa krajowego stojącego na przeszkodzie (nawet tymczasowo) pełnej skuteczności norm wspólnotowych. Z taką sytuacją mielibyśmy do czynienia, gdyby - w przypadku niezgodności między prawem wspólnotowym a późniejszym prawem krajowym - rozstrzygnięcie konfliktu należało do organu innego niż orzekający w sprawie sąd, na którym ciąży obowiązek zapewnienia pełnej skuteczności prawu wspólnotowemu. Nie zmienia powyższej oceny tymczasowy charakter przeszkody w zapewnieniu prawu wspólnotowemu pełnej skuteczności.

W wyroku w sprawie C-2138910 Factortame z dnia 19 czerwca 1990 r. (pytanie prejudycjalne) TSUE stwierdził, że pełna skuteczność prawa wspólnotowego wymaga, aby w przypadku sądowego sporu o istnienie prawa podmiotowego chronionego przez prawo wspólnotowe istniała możliwość wydania zabezpieczenia tymczasowego. Jeżeli sprzeciwiają się temu przepisy prawa krajowego sąd, który uznaje za zasadne orzeczenie takiego zabezpieczenia, musi odmówić ich zastosowania.

W wyroku z dnia 27 czerwca 1991 r. w sprawie C-348/8916 Mecanarte (pytanie prejudycjalne) TSUE stwierdził, że skuteczność prawa wspólnotowego byłaby zagrożona, gdyby obowiązek zainicjowania postępowania przed sądem konstytucyjnym stał na przeszkodzie skorzystania przez sąd krajowy, rozstrzygający sprawę, w której znajduje zastosowanie prawo wspólnotowe, z przyznanej mu na mocy art. 267 TFUE kompetencji do przedstawienia TSUE pytania w trybie prejudycjal- 
nym. Rozstrzygający taką sprawę sąd krajowy, który ocenia przepisy prawa krajowego jako niezgodne z konstytucją, nie jest pozbawiony uprawnienia ani zwolniony z obowiązku przedstawienia TSUE pytania w trybie prejudycjalnym.

Ponadto, zgodnie z utrwaloną linią orzecznictwa TSUE i w świetle wynikającego z art. 234 TWE podziału kompetencji między sądy krajowe a TSUE, do sądu krajowego należy ocena, czy rozstrzygnięcie kwestii dotyczącej prawa wspólnotowego jest konieczne do wydania orzeczenia w sprawie. Dotyczy to także oceny, na którym etapie postępowania należy przedstawić TSUE pytanie w trybie prejudycjalnym.

W wyroku z dnia 2 lipca 1996 r. w sprawie C-473/9319, Komisja przeciwko Luksemburgowi (skarga na uchybienie zobowiązaniom) TSUE orzekł, że odwoływanie się do przepisów krajowych w celu ograniczenia skutków obowiązywania norm prawa wspólnotowego podważałoby jednolitość i skuteczność tego prawa. W konsekwencji niedopuszczalne jest powoływanie się przez Luksemburg na art. 11 ust. 2 Konstytucji, zgodnie z którym wyłącznie obywatele luksemburscy mogą być zatrudniani na stanowiskach cywilnych i wojskowych.

Trybunał Sprawiedliwości Unii Europejskiej korzysta przy interpretacji prawa z dziedzictwa wypracowanego przez tradycję prawną wszystkich państw członkowskich. Formalnie nie jest związany swoimi wcześniejszymi orzeczeniami, aczkolwiek konsekwentnie odmawia zmiany raz wyrażonego stanowiska kwestii prawnej przytaczając w uzasadnieniu swoje poprzednie orzeczenia dotyczące przedmiotu wykładni. Orzeczenia TSUE posiadają ex lege moc powszechnie obowiązującą jedynie w Wielkiej Brytanii i w Irlandii. W literaturze słusznie podnosi się, że orzeczenia TSUE to nie tylko odtwórcza interpretacja przepisów traktatowych, ale także współtworzenie prawa przy wykorzystaniu reguł pozatekstowych i wykładni celowościowej. ${ }^{24}$ Interpretacja aktów wspólnotowych dokonywana przez TSUE w oparciu o art. 267 TFUE ma moc nie tylko dla sądów krajowych, które zwróciły się o nią w związku z rozpatrywaną sprawą, lecz dla wszystkich sądów państw członkowskich, ilekroć przyjdzie im stosować dany przepis i to tak długo, jak długo Trybunał nie zmieni dokonanej wcześniej wykładni. 
THE ROLE OF THE ECJ CASE-LAW IN THE PROCESS OF HARMONIZATION OF EU LAW WITH NATIONAL LAW

Keywords: agricultural law, European Union law, the Court of Justice of the European Union

Upon entry into force of the accession treaty, Poland - as a member state of the European Union - became bound by the body of EU law (the acquis communautaire), including its primary and secondary law as well as the interpretation of EU law contained in the Court of Justice of the European Union case-law.

Due to a very close approximation of Polish legislation to EU law - resulting from the obligation to consider, employ, and apply in the process of implementing the former a number of EU legal acts, i.e. regulations, directives, as well as acts of soft law such as guidelines and recommendations that are not acts of common law the problem of the scope of application of EU law within the Polish legal system has occurred; this problem, or a gap in the legal sense, has been addressed and resolved, to a large extent, by case-law of the CJEU.

\section{Bibliografia:}

Albisinni F., Europejskie prawo rolne po Traktacie z Lizbony pomiędzy interwencją a regulacją. Europejskie kodeksy rolnictwa, „Przegląd Prawa Rolnego”, Nr 1 (8)-2011.

Barcz J., Stosowanie prawa Wspólnot Europejskich w państwach członkowskich, Warszawa 1991.

Biuro Trybunału Konstytucyjnego Zespół Orzecznictwa i Studiów „Zasada pierwszeństwa prawa wspólnotowego w krajowych porządkach prawnych według orzecznictwa ETS i Sądu Pierwszej Instancji”. Omówienia wybranych orzeczeń (1963-2005), (red.) P. Miklaszewicz (red.).

Costato L., Agricoltura, [w:] M. Chiti, G. Greco (red.), Trattato di diritto amministrativo europeo, t. I, Milano 1957.

Dauses M. A., Prawo Wspólnot Europejskich a prawo niemieckie w świetle niemieckiego porządku konstytucyjnego, „Przegląd Prawa Egzekucyjnego” 1998, nr 1.

Górska M., Relacje między prawem wspólnotowym, a prawem krajowym w prawie i praktyce sądowej państw członkowskich Unii Europejskiej, [w:] C. Banasiński, J. Oniszczuk (red.), Konstytucja - Trybunał Konstytucyjny, Warszawa 1998, s. 94 i n.

Kukuryk K., Kilka uwag na temat sądowej wykładni prawa, [w:] Europeizacja prawa krajowego. Wpływ integracji europejskiej na klasyczne dziedziny prawa krajowego, C. Mik (red.), Toruń 2000.

Mik C., Metodologia implementacji europejskiego prawa wspólnotowego w krajowych porządkach prawnych, [w:] Implementacja prawa integracji europejskiej w krajowych porządkach prawnych, C. Mika (red.), Toruń 1998.

E. Podgórska, Problem pierwszeństwa prawa Wspólnot Europejskich wobec prawa krajowego w orzecznictwie włoskiego Trybunału Konstytucyjnego, „Państwo i Prawo” 1994, nr 11. 
Rabska T., Administracja publiczna w świetle integracji z Unią Europejską, „Samorząd Terytorialny” 2003 , nr 3 .

Rydlewski G., Europeizacja administracji publicznej w Polsce, [w:] Administracja publiczna w procesie dostosowywania państwa do Unii Europejskiej, T. Mołdawa, K.A. Wojtaszczyk, M. Malecki (red.), Warszawa 2003.

Saganek P., Orzecznictwo sądów krajowych państw członkowskich dotyczące Wspólnot Europejskich, [w:] C. Mik (red.), Wymiar sprawiedliwości w Unii Europejskiej, Toruń 2001.

Zaleśkiewicz M., Co mówi prawo? Uwagi nad prawotwórczą wykładnią funkcjonalną w orzecznictwie Sądu Najwyższego Stanów Zjednoczonych i Europejskiego Trybunału Sprawiedliwości, http://www.mishellanea.mish.uw.edu.pl/wp-content/uploads/2010/03/Zale\%C5\%9BkiewiczCo-m\%C3\%B3wi-prawo.pdf, (data dostępu: 5.11.2016 r.). 